Article

\title{
Annual Prediction Output of an RADTIRC-PV Module
}

\author{
Daria Freier 1,*, Firdaus Muhammad-Sukki ${ }^{2, *}$ (iD , Siti Hawa Abu-Bakar ${ }^{3}$, \\ Roberto Ramirez-Iniguez ${ }^{1}$, Abu Bakar Munir ${ }^{4,5}$, Siti Hajar Mohd Yasin ${ }^{6}$, Nurul Aini Bani ${ }^{7, *}$, \\ Abdullahi Abubakar Mas'ud ${ }^{8}$, Jorge Alfredo Ardila-Rey ${ }^{9}$ and Md Ershadul Karim ${ }^{4}$ (D) \\ 1 School of Engineering \& Built Environment, Glasgow Caledonian University, 70 Cowcaddens Road, \\ Glasgow G4 0BA, UK; rra4@gcu.ac.uk \\ 2 School of Engineering, Robert Gordon University, Garthdee Road, Aberdeen AB10 7GJ, UK \\ 3 British Malaysian Institute, Universiti Kuala Lumpur, Batu 8, Jalan Sungai Pusu, Gombak 53100, Malaysia; \\ hawa012@gmail.com \\ 4 Faculty of Law, University of Malaya, Kuala Lumpur 50603, Malaysia; abmunir@um.edu.my (A.B.M.); \\ ershadulkarim@gmail.com (M.E.K.) \\ 5 University of Malaya Malaysian Centre of Regulatory Studies (UMCoRS), University of Malaya, \\ Jalan Pantai Baru, Kuala Lumpur 59990, Malaysia \\ 6 Faculty of Law, Universiti Teknologi MARA, Shah Alam 40450, Malaysia; smohdyasin@yahoo.com \\ 7 UTM Razak School of Engineering and Advanced Technology, Universiti Teknologi Malaysia, \\ Kuala Lumpur 54100, Malaysia \\ 8 Department of Electrical and Electronics Engineering, Jubail Industrial College, P.O. Box 10099, \\ Jubail 31961, Saudi Arabia; masud_a@jic.edu.sa \\ 9 Department of Electrical Engineering, Universidad Técnica Federico Santa María, \\ Santiago de Chile 8940000, Chile; jorge.ardila@usm.cl \\ * Correspondence: daria.freier@gcu.ac.uk (D.F.); f.b.muhammad-sukki@rgu.ac.uk (F.M.-S.); \\ nurulaini.kl@utm.my (N.A.B.)
}

Received: 15 January 2018; Accepted: 1 March 2018; Published: 3 March 2018

\begin{abstract}
The number of solar photovoltaic (PV) installations has been increasing worldwide but the high capital cost of installation continues to be the main challenge, particularly in many developing countries. The solar concentrator, a device that focuses the sunlight onto a small area, has the potential to minimize the use of expensive PV material while maintaining the system's performance, ultimately bringing down its overall cost. This study aims to predict the annual electrical output of a specific concentrator design called the rotationally asymmetrical dielectric totally internally reflecting concentrator (RADTIRC). The aforementioned design is assumed to be installed in Berlin/Brandenburg, Germany. First, a short review of concentrators is provided. Next, a description of the RADTIRC and the previous research that revolved around it are provided. Afterwards, the key parameters that are needed to determine the annual electrical output of the RADTIRC are explained before presenting the results of the simulations. It was found that the yearly energy yield was increased by a factor of 2.29 when the RADTIRC-PV module was used when compared with the non-concentrating PV module.
\end{abstract}

Keywords: photovoltaic; optical concentrator; rotationally asymmetrical dielectric totally internally reflecting concentrator; annual output; Berlin

\section{Introduction}

Access to energy is integral to global development in the 21st century [1]. The four dimensions of the Sustainable Development Goal (SDG) 7 are affordability, reliability, sustainability, and modernity. 
Often, these dimensions could not exist on their own and are seen overlapping, in some cases even needing each other [1]. The United Nations (UN) states the targets for 2030 as follow [2]:

“..(1) to ensure universal access to affordable, reliable and modern energy services; (2) to increase substantially the share of renewable energy in the global energy mix; (3) to double the global rate of improvement in energy efficiency; (4) to enhance international cooperation to facilitate access to clean energy research and technology, including renewable energy, energy efficiency and advanced and cleaner fossil-fuel technology, and to promote investment in energy infrastructure and clean energy technology, and (5) to expand infrastructure and upgrade technology for supplying modern and sustainable energy services for all in developing countries, in particular in the least developed countries, small island developing states, and land-locked developing countries, in accordance with their respective programs of support."

To mobilize efforts to achieve sustainable energy and the newly adopted SDG 7, the UN Sustainable Energy for All (SE4ALL) global initiative was launched and the International Renewable Energy Agency (IRENA) serves as the initiative's Renewable Energy Hub [3]. In this role, IRENA has produced the Global Renewable Energy Roadmap (REmap 2030) that identifies various routes to potentially raise the renewables' share in the global energy mix by $100 \%$ [3].

According to the Intergovernmental Panel on Climate Change (IPCC), solar has "the largest technical potential" when compared with other renewables [4]. Chen [5] calculated that the sun produces $5.46 \times 10^{6} \mathrm{EJ} /$ year over the earth's surface; more than 10,000 times the annual energy needed by the world in 2005-2010. Another calculation by Lewis and Nocera [6] indicated that one hour of energy from the sun is sufficient to satisfy the world's energy consumption of 2001. The IEA in its 2014 report predicted that solar power could become the dominant power source by 2050 [7]. To harvest solar energy, the solar photovoltaic (PV) system is widely adopted. This technology transforms the energy from the sun directly into electricity. Based on the analysis by Luque and Hegedus [8], it was demonstrated that by installing a solar PV system with an efficiency of only $10 \%$ in $0.4 \%$ of the earth's land area could have been sufficed to meet the world's energy requirement (electricity, heat, and transportation) in 2010.

In the last 10 years, solar PV has seen a significant growth around the globe. Solar PV added an additional capacity of $75 \mathrm{GW}$ in 2016, making it reached a new cumulative installation of $303 \mathrm{GW}$ [9]. The majority of the new installations in 2016 were carried out in China, United States of America, Japan, India, and the United Kingdom-totaling to about $85 \%$ of the PV share [9]. China and Japan now overtook Germany in terms of being a global leader in solar PV installations- this is because of the introduction of feed-in tariff scheme which stimulates the uptake of solar PV in those countries [9]. With a continuous huge investment in solar technology totaling to \$1133.6 billion from 2006 to 2016 (see Figure 1), this technology has created around 3.1 million jobs worldwide, which corresponds to $31 \%$ of the renewable energy job markets in 2016 [9].

In spite of the oversupply and decreasing prices of PV modules, the cost to install a PV system is still perceived as very expensive in many countries. The International Energy Agency Photovoltaic Power Systems Programme (IEA-PVPS) has presented a summary of the installation cost in 20 countries in 2015 [10], for the off-grid and on-grid (covering the residential, commercial, industrial and ground-mounted sectors) connections. According to the report, for off-grid installations, the cost of installation ranged between $\$ 2.23 / \mathrm{W}$ and $\$ 18.59 / \mathrm{W}$. As for on-grid installations, it varied according to the sectors: from $\$ 0.95 / \mathrm{W}$ to $\$ 4.96 / \mathrm{W}$ for the residential sector (see Figure 2), from $\$ 0.89 / \mathrm{W}$ to $\$ 3.12 / \mathrm{W}$ for the commercial sector, from $\$ 1.11 / \mathrm{W}$ to $\$ 2.03 / \mathrm{W}$ for the industrial sector and from $\$ 0.74 / \mathrm{W}$ to $\$ 2.03 / \mathrm{W}$ for the ground-mounted sector.

Based on the IEA-PVPS analysis, the PV module contributed between $40 \%$ and $50 \%$ of the total cost of installation [10]. The IRENA [11] reported that the variations of installation cost were due to many factors, including: (i) the PV module characteristics (module type, installation size); (ii) the sectors (on-grid or off-grid; residential, commercial, industrial or ground mounted); (iii) the incentives 
in place in each country (policy, loan, subsidies, tax exemption); and (iv) the countries' PV market (maturity, size).

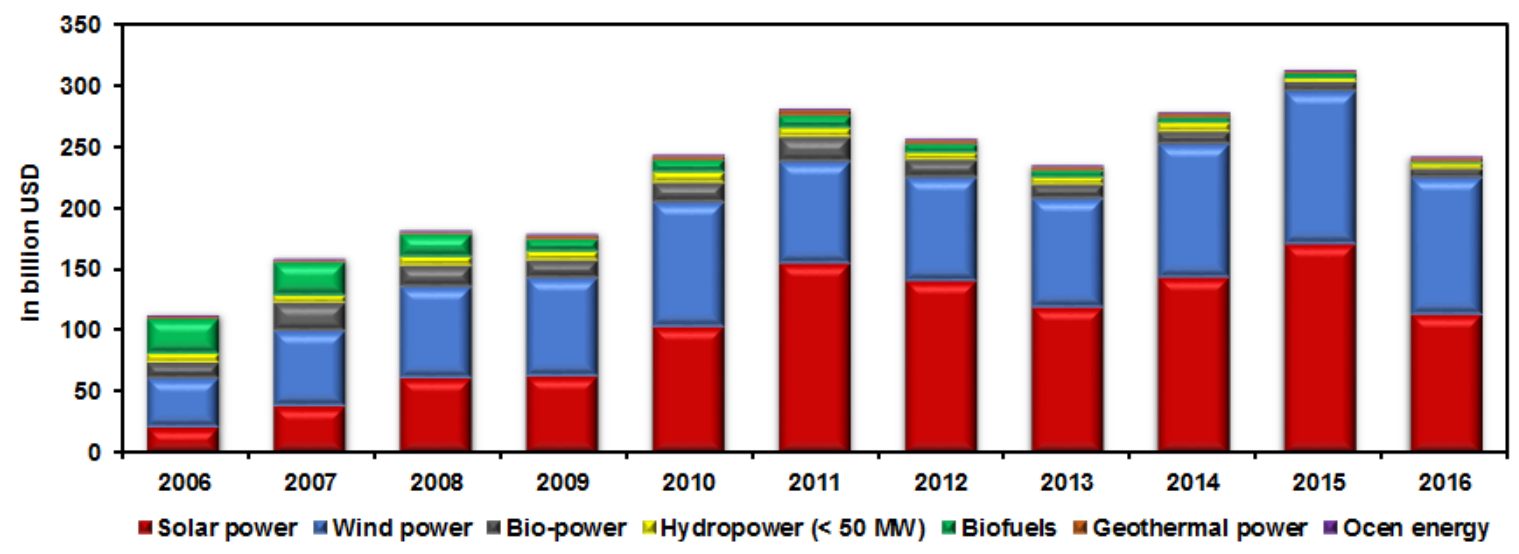

Figure 1. Breakdown of new investment by technology. Adapted from [9].

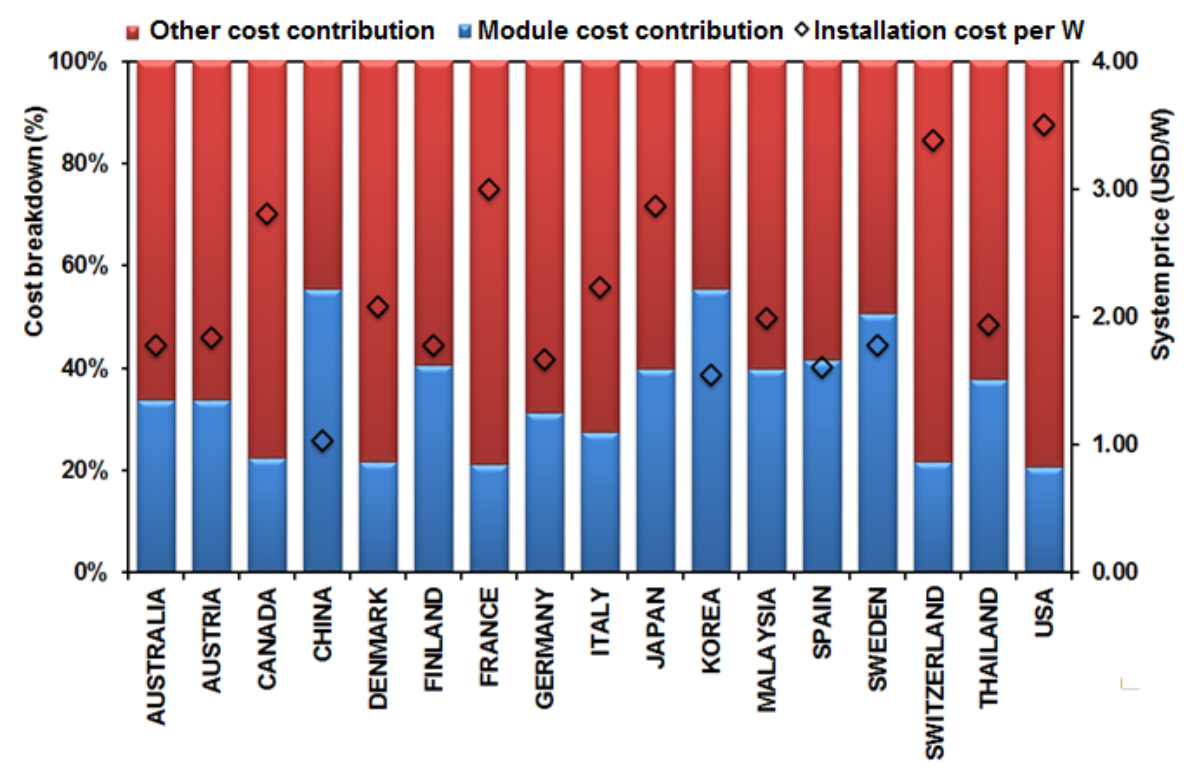

Figure 2. Breakdown of an average on-grid solar photovoltaic (PV) installation cost in 2015 in residential buildings. Adapted from [10].

The cost of installation plays a critical role in attracting consumers to install any solar PV system [12]. To achieve the targets discussed in the previous sections, it is imperative to bring the installation cost further down to incentivize more installations. This will help to further push the contribution of solar PV in satisfying the global electricity need from only 1.2\% [10] at the moment to a much greater percentage.

One of the ways of lowering the cost is by reducing the amount of expensive PV material that dominates up to $73 \%$ [13] of the PV module cost, i.e., the PV material represents as high as $36.5 \%$ of the overall cost of installation. In order to minimize the amount of PV material whilst maintaining the electrical output from the PV module, some researchers proposed to integrate a solar concentrator in the PV module [14-16], producing a concentrating PV (CPV) system. In general, a CPV device can be divided into three sections: the entrance aperture, the exit aperture (for an imaging CPV device, the dimension of the solar cell is used instead of the exit aperture). and the reflector/refractor [17]. The entrance aperture enables the solar energy to enter the concentrator, and the reflector/refractor directs 
the solar energy to the exit aperture. More detailed descriptions on the fundamental concentrator concepts have already been covered by several authors [8,18-22]. To date, there are various concentrator designs being developed and tested by various institutions.

Today, the search for a low cost highly efficient CPV system still continues [23]. Interestingly, besides focusing on devising the best concentrator for a power plant, the research also started to pay more attention to the usage of concentrators for building integration applications [24-27], researching specifically on the low concentration concentrator. The combination of a low concentration photovoltaic (LCPV) structure for building integration is known as building integrated concentrating photovoltaic (BICPV) system.

There are many advantages and disadvantages of utilizing the BICPV system which are almost similar to building integrated PV (BIPV) system, and these are summarized in Table 1.

Table 1. The advantages and disadvantages of using a building integrated concentrating photovoltaic (BICPV) system.

\begin{tabular}{l} 
Advantages \\
\hline Cheaper panel cost due to the reduction in the use of \\
expensive PV material, as long as the cost of the \\
concentrator is cheaper than the cost of displaced PV \\
material [28]. \\
For building integration, other cost saving potential \\
include: (i) eliminating the additional cost of \\
infrastructure to mount the panels, which is required for \\
ground mounted installation; (ii) eliminating the cabling \\
cost to connect the installation to the grid can be reduced \\
because almost all buildings are connected to the national \\
grid, unlike the installation in isolated PV farms; and \\
(iii) reducing the building material cost can be reduced \\
since the panel replaces part of the building structure \\
(e.g., roof, façade and window) [29].
\end{tabular}

Generate more electrical output when the LCPV is compared with a non-concentrating design that uses the same area of PV material. The concentrator increases the opto-electronic gain under both direct and diffuse radiations [33].

Eliminate the need for electromechanical sun tracking system due to its wide half-acceptance angle [34].

The land area requirement can be eliminated since the installation is carried out on an existing building structure [34]. This is beneficial especially for installation in urban areas.

The electricity generated can be consumed by the building, which reduces the electricity bill since the generation coincide with the electricity demand of the day. Additionally, the electricity could also be fed back into the national grid [36].
The concentrator requires precise machining during the manufacturing process to ensure optimum performance. This could increase the cost of the panel.

A BICPV system is could also be more expensive than a standard mass-marketed roof/façade-mounted PV system. Some of the reasons include: (i) willingness of customers to pay premium for its speciality function [30]; (ii) difficulties in creating a good supply chain for BICPV products and services [30]; (iii) additional materials' cost in the modules [31]; and (iv) further labour cost associated with specialized architectural design, engineering design and installation [32].

May operate at higher temperatures than a conventional rack-mounted PV because they are integrated to the surface of the building and therefore prevents airflow between the modules and the host structure [30]. A higher temperature will lower the electrical output of the panel and may degrade the PV material of the module.

Tends to produce less electricity than conventional rack-mounted PV because it might not be integrated at optimum angle with respect to the sun and the problem with shadowing from surrounding buildings [30].

Require complex design requirement which revolves around identifying the 'perfect' balance between the output power, the system cost and the aesthetics [35]. This is different than the conventional roof/façade-mounted PV system which focuses only on either electricity or aesthetics. Therefore, any installation of a BICPV system needs to take into account building process, building physics, energetic design, aesthetical concept and economical concept [34,35].

A BICPV system not only generates electricity, but it also acts as parts of the building structure. Therefore, it needs to comply with the codes and standards of both PV and construction industries [30]. This means that it not only needs to adhere to the qualification and design standards of a PV module, it must also meet the criteria of a building structure, e.g., stability, wind resistance, durability, fire safety, etc. [37]. This creates a market handicap for the BICPV system when compared to the conventional roof/façade-mounted PV system [30]. 
Table 1. Cont.

\begin{tabular}{ll}
\hline \multicolumn{1}{c}{ Advantages } & \multicolumn{1}{c}{ Disadvantages } \\
\hline & $\begin{array}{l}\text { There is a huge variety of BICPV products, either by façade } \\
\text { type (e.g., curtain walls, windows, roof shingles and } \\
\text { awnings) [30] or by design (e.g., geometries and materials) } \\
\text { [34]. This leads to BIPV market being focused on } \\
\text { custom-design segment which hinders the scalability of } \\
\text { BIPV technology. In addition to that, its limitation of only } \\
\text { being suitable for residential and commercial building } \\
\text { integration eliminates its prospect to compete with } \\
\text { utility-scale and ground-mount space [30]. }\end{array}$ \\
$\begin{array}{l}\text { The co-generated heat can be used to heat/cool the } \\
\text { building interior, reducing the heating/cooling } \\
\text { requirement of a building [38]. }\end{array}$ & \\
$\begin{array}{l}\text { The arrangement of the PV cells can be designed in such } \\
\text { a way that it could allow natural illumination into the } \\
\text { building, which could reduce the lighting requirement of } \\
\text { a building [38]. }\end{array}$ & \\
\hline $\begin{array}{l}\text { The losses due to transmission and distribution of } \\
\text { electricity can be minimized because the electricity is } \\
\text { consumed onsite [34]. }\end{array}$ \\
$\begin{array}{l}\text { A BICPV system can enhance the aesthetic appearance of } \\
\text { a building by introducing innovative ways of integrating } \\
\text { the panel in the building [17]. }\end{array}$
\end{tabular}

Abu-Bakar et al. investigated a rotationally asymmetrical compound parabolic concentrator (RACPC) which could potentially increase the maximum output power by 3.33 times when compared with a bare cell $[39,40]$. A small window incorporating the RACPCs was further constructed and from the experiments, the window achieved a power gain close to 3 when compared with the non-concentrating window [41]. Singh et al. [42] compared the performance of two line-axis concentrator, a V-trough and compound parabolic concentrator (CPC) and found that the former outperformed the latter by producing 17.2\% more electrical output. Bojić et al. [43] evaluated three types of sea-shell trough concentrators and concluded that the optical efficiencies of these concentrators were highly dependent on the altitude of the sun ray incidence, i.e., each one was best suited for a specific location. Wu et al. [44] constructed a smart CPV system that included a thin layer of hydrogel/polymer thermotropic coating laminated onto a window glass sheet. The thermotropic layer reacted differently depending on the heat that it was exposed to, i.e., it became translucent during summer and became clear during winter. The system not only generated electricity (i.e., $57 \mathrm{~W}$ for the tested prototype), but it also acted as a shade during summer time and allowed natural illumination during winter time, hence reducing the electricity requirement of the building. Meng et al. [45] invented a novel PV/thermal system called the absorptive/reflective crossed CPC (AR-CCPC). The top part of the AR-CCPC was designed to absorb the heat, which can be used for water and space heating while the bottom part (to which a PV cell is attached) produced the electricity. Their design increased the electrical output 3.23 times when compared with a non-concentrating PV cell. The top part of the AR-CCPC managed to absorb heat with the highest temperature recorded at $321.5^{\circ} \mathrm{K}$.

Slooff et al. [46] demonstrated a luminescent solar concentrator (LSC) made from a polymethylmethacrylate (PMMA) plate doped with two types of dye. When coupled with gallium arsenide (GaAS) solar cells, their LSC design achieved an electrical conversion efficiency of 7.1\%. Lo et al. [47] created a new algorithm to evaluate the performance of an LSC and concluded that their new method is "a fast, powerful and cost-effective tool" to design any LSC. Pei et al. [48] showed that the optical efficiency of a dielectric CPC can be improved by introducing a mirror coating on the sides of the concentrator, as high as $13.5 \%$. Vu and Shin [49] evaluated a prism-CPC and showed that such system could obtain an $89 \%$ optical efficiency. Tien and Shin [50] on the other hand showed that by adding a secondary concentrator to the existing Fresnel lens CPV system, the optical power ratio can be raised by approximately $17.12 \%$. Liu et al. [51] proposed a planar concentrator that is coupled with Lambertian reflector at the back. Their concentrator design managed to increase the performance by 
1.4 times when compared with the bare cell. Meng et al. [52] created a freeform reflective concentrator by using a complex algorithm. This design was demonstrated to achieve a uniform flux distribution on either circular or rectangular target.

Selvaraj et al. [53] utilized a 3D printed CPC to increase the efficiency of dye-sensitized solar cells (DSSCs) to $5.93 \%$ as compared to $2.64 \%$ generated by the scale-up non-concentrating DSSCs. Meanwhile, van Dijk et al. [54] studied an external light trapping device-a 3D printed parabolic concentrator and a spacer-and showed that this device enhanced the generation of short circuit current of the thin film cell by $13 \%$. Price et al. [55] suggested a compact microcell CPV with microcell PVs placed in between an acrylic lenslet array and a reflective acrylic mirror array. With a geometrical concentration gain of $>200$, the system was capable of increasing the energy yield by 1.9 times when compared to the non-concentrating counterpart.

While most of the research only focused on the optical and electrical performances of the concentrators, some authors also investigated the economic aspect of the system. Abu-Bakar et al. [56] indicated that the inclusion of RACPC in the PV module could reduce the module cost by $31.75 \%$ as compared to the non-concentrating counterpart. Sarmah et al. [57] showed that their CPV design which utilized an asymmetrical CPC could cut the solar panel cost per $\mathrm{kW}$ by $20 \%$ when compared with a non-concentrating PV panel. Another analysis by Muhammad-Sukki et al. [36] showed that their optimized concentrator design could minimize the overall cost of installation by $41 \%$ when compared to a non-concentrating system.

The concentrator investigated in this paper is called the rotationally asymmetrical dielectric totally internally reflecting concentrator (RADTIRC). It focuses on the formulations to predict the annual electrical output of an RADTIRC-PV system installed in Berlin. Section 2 gives an overview of the RADTIRC and summarizes the previous works involving this concentrator. Section 3 provides the key parameters needed to calculate the annual electricity yields. Afterwards, Section 4 presents the results from the simulations before presenting the conclusions at the end of the paper.

\section{RADTIRC-What Has Been Achieved}

The RADTIRC was first developed by Ramirez-Iniguez et al. [58] to provide a higher electrical output, thus minimizing the usage of expensive PV material, and ultimately reducing the PV system cost [38]. The steps to produce the RADTIRC have been explained in detail by Ramirez-Iniguez et al. [58]. Muhammad-Sukki et al. [38] wrote a MATLAB code to help visualize and investigate the geometrical properties of the RADTIRC design. A variety of concentrators from this family have been created and simulated to evaluate their optical concentration gains [38]. The analysis on the geometrical properties of the RADTIRC provides information on the physical dimensions (i.e., total height, entrance aperture area) of the concentrator, as well as its geometrical concentration gain. They concluded that an RADTIRC with a higher geometrical concentration gain has a smaller half-acceptance angle and corresponds to a much larger structure, and vice versa [38]. The optical concentration gain, on the other hand, predicts the electrical output that could be generated by each RADTIRC-PV cell, as well as examines the light distribution on the cell. Their analysis indicated that an RADTIRC with a wider half-acceptance angle captures the sun energy for a much longer period of time in a day than the one designed with a smaller half-acceptance angle [38]. Based on these investigations, they concluded that a smaller concentrator with a wider half-acceptance angle and a smaller geometrical concentration gain is more desirable than the ones with a smaller half-acceptance angle and a higher geometrical concentration gain because [38]: (i) it utilizes less material, which reduces the material cost; (ii) it collects the sunlight for longer durations during the day; and (iii) the design produces a more uniform flux distribution which generates less 'hot spots' on the PV cell, leads to a lower temperature, and ultimately enables the RADTRIC-PV structure to operate at its optimum efficiency level.

One particular RADTIRC design was manufactured and tested both indoors and outdoors in May 2012 [59]. It has a geometrical concentration gain of 4.91, a total height of $3 \mathrm{~cm}$, a square exit aperture with sides of $1 \mathrm{~cm}$ and, two half-acceptance angles of $\pm 30^{\circ}$ along the $z$-axis (north-south axis) and $\pm 40^{\circ}$ 
along $x$-axis (the east-west axis) respectively [59]. The first prototype was fabricated from a type of acrylic known as "6091" (supplied from Renishaw Plc., Wotton-under-Edge, Gloucestershire, UK) with an index of refraction of 1.515 by using a silicon mold [59]. The experiments include characterizing the RADTIRC-PV cell, investigating its angular response as well evaluating the effect of temperature on the structure. The results from the experiments showed the opto-electronic gain reached its peak value of 4.2 at $0^{\circ}$ inclination when compared with a bare PV cell [59].

The first prototype suffered from shrinkage during the manufacturing process, as well as discoloration and photodegradation which showed a reduction of $7.84 \%$ in terms of the maximum output power after 2 years (measured in June 2014). To address these issues, a second optimization was carried out by Abu-Bakar et al. [28]. The design was optimized by using a better material known as Altuglas ${ }^{\circledR}$ V825T, a variation of PMMA. The prototype was produced this time using injection molding, which is known to be one of the most cost-effective solutions in mass producing any components, including solar concentrators. The experimental results showed that the optimized design achieved an opto-electronic gain of 4.48 , a $14 \%$ increase from one produced by the first prototype. The summary of the analysis is presented in Table 2.

Table 2. Performances of the RADTIRCs (measured in June 2014).

\begin{tabular}{|c|c|c|c|}
\hline Item & $\begin{array}{l}\text { Computer-Aided } \\
\text { Design (CAD) }\end{array}$ & $\begin{array}{l}\text { First RADTIRC } \\
\text { Prototype }\end{array}$ & $\begin{array}{c}\text { Second RADTIRC } \\
\text { Prototype }\end{array}$ \\
\hline \multicolumn{4}{|l|}{$\begin{array}{c}\text { Photograph (refer axis below) } \\
\text { y }\end{array}$} \\
\hline Material & $\mathrm{n} / \mathrm{a} *$ & 6091 & PMMA \\
\hline Fabrication technique & $\mathrm{n} / \mathrm{a} *$ & Silicon moulding & Injection moulding \\
\hline Length along $x$-axis (cm) & 2.21 & 2.14 & 2.28 \\
\hline $\begin{array}{l}\text { Change with respect to the } \\
\text { CAD design-along } x \text {-axis (\%) }\end{array}$ & $\mathrm{n} / \mathrm{a}$ * & -2.99 & 3.35 \\
\hline Length along $y$-axis $(\mathrm{cm})$ & 2.64 & 2.55 & 2.57 \\
\hline $\begin{array}{l}\text { Change with respect to the } \\
\text { CAD design—along } y \text {-axis (\%) }\end{array}$ & $\mathrm{n} / \mathrm{a}$ * & -3.26 & -2.50 \\
\hline Area $\left(\mathrm{cm}^{2}\right)$ & 5.815 & 5.46 & 5.86 \\
\hline $\begin{array}{l}\text { Change with respect to the } \\
\text { CAD design-Area }(\%)\end{array}$ & $\mathrm{n} / \mathrm{a}^{*}$ & -6.10 & 0.77 \\
\hline $\begin{array}{l}\text { Maximum Short circuit } \\
\text { current, } I_{S C}(\mathrm{~mA})\end{array}$ & $\mathrm{n} / \mathrm{a}$ * & 140.00 & 159.00 \\
\hline Open circuit voltage, $V_{o c}(\mathrm{~V})$ & $\mathrm{n} / \mathrm{a}$ * & 0.61 & 0.61 \\
\hline Maximum Power, $P_{\max }(\mathrm{mW})$ & $\mathrm{n} / \mathrm{a} *$ & 66.38 & 75.91 \\
\hline $\begin{array}{l}\text { Maximum Optical efficiency, } \\
C_{\text {eff }}(\%)\end{array}$ & 94.20 & 80.14 & 91.27 \\
\hline $\begin{array}{l}\text { Maximum Opto-electronic } \\
\text { gain, } C_{o p t}\end{array}$ & 4.62 & 3.93 & 4.48 \\
\hline Fill Factor, FF (\%) & $\mathrm{n} / \mathrm{a}$ * & 77.72 & 78.26 \\
\hline $\begin{array}{l}\text { Maximum Electrical } \\
\text { conversion efficiency, } \eta(\%)\end{array}$ & $\mathrm{n} / \mathrm{a}$ * & 13.45 & 15.45 \\
\hline
\end{tabular}

${ }^{*} \mathrm{n} / \mathrm{a}=$ not applicable.

Another analysis was performed to investigate the effect of diffuse radiation on the RADTIRC. Freier et al. $[33,60]$ concluded that the RADTIRC has an opto-electronic gain of 2.13 under diffuse radiation. A solar window that employed 12 RADTIRCs was also constructed (see Figure 3 ) and tested indoors, achieving a maximum opto-electronic gain of 4.13 when compared to a non-concentrating PV window [61]. The panel was also tested outdoors for 4 days in Glasgow, United Kingdom 
in 2014. As expected, the RADTIRC-PV panel produced a higher short-circuit current than the non-concentrating panel for sun rays captured within its half-acceptance angle [61] (e.g., see Figure 4). Due to lack of equipment, the study did not differentiate the contribution from direct nor diffuse solar irradiance to the electrical output of the concentrator, rather it considered the total contribution from both components.
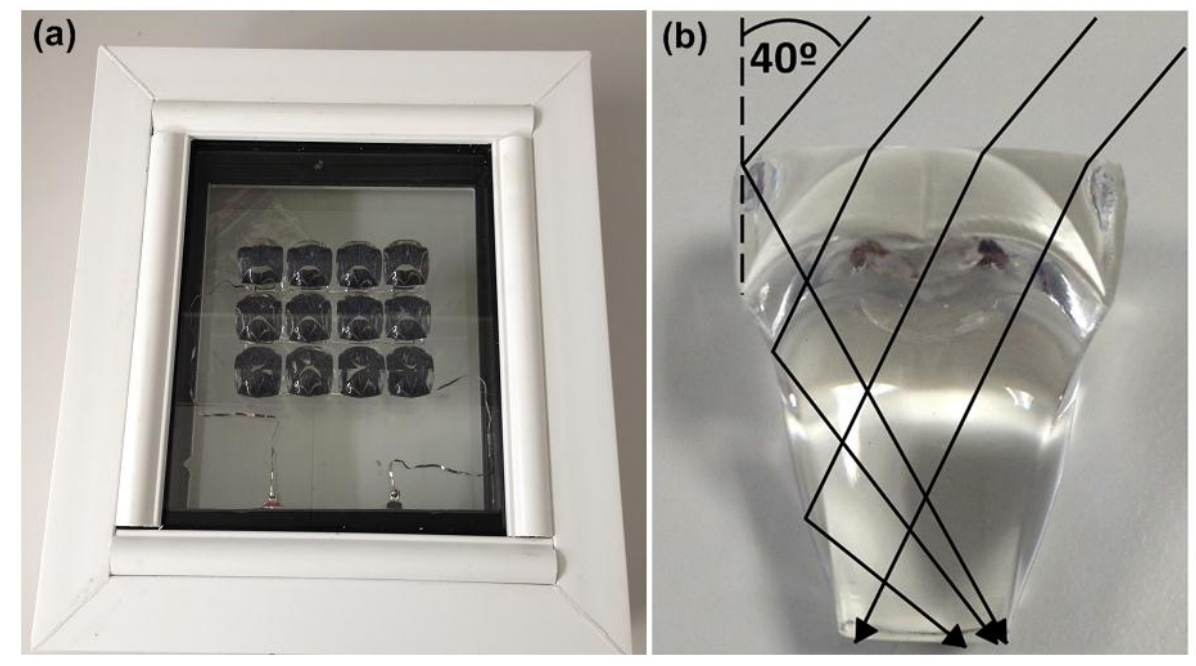

Figure 3. (a) A concentrating PV (CPV) window incorporating rotationally asymmetrical dielectric totally internally reflecting concentrators (RADTIRCs); and (b) the half-acceptance angle of the RADTIRC.

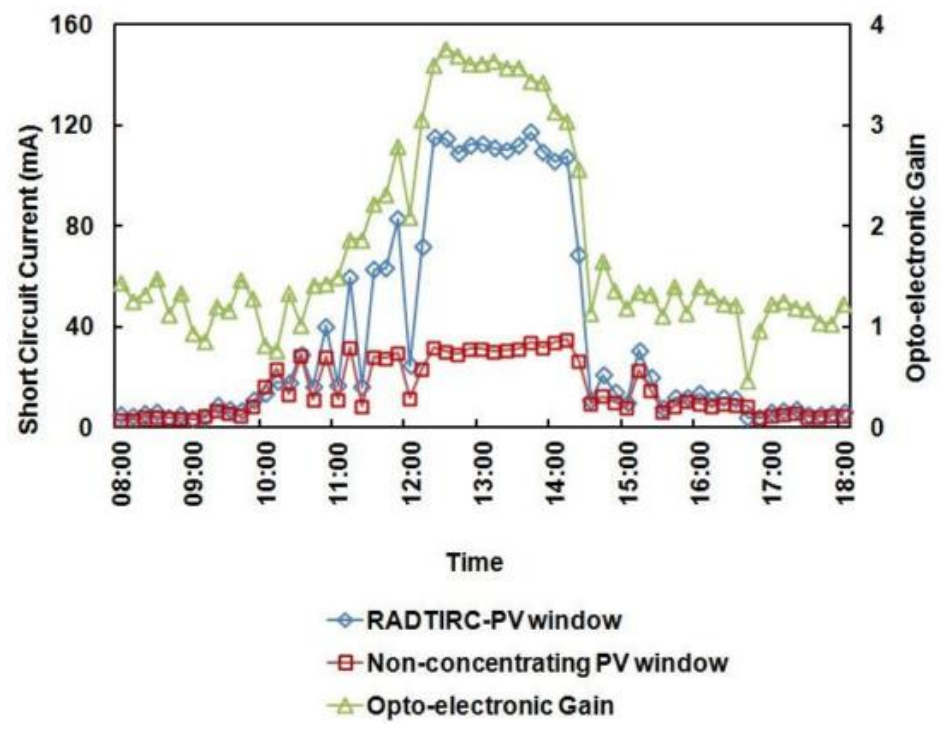

Figure 4. The outdoor experiments in Glasgow, during an almost clear sky day. Adapted from [61].

Having done all the tests, the data from simulations and experiments could be used to predict the annual performance of an RADTIRC-PV module. This information is crucial to the stakeholders since it demonstrates the viability of such system to become a substitute to the traditional non-concentrating PV system. Such analysis has also been demonstrated by other CPV researchers. For example, Lamnatou et al. [62] calculated theoretically that a $1 \mathrm{kWp}$ of solar panel incorporating an array of dielectric CCPC could generate approximately $1140 \mathrm{kWh} /$ year if such system were installed in Barcelona, Spain. Baig et al. [63] carried out another analysis involving a solar panel that incorporated a linear dielectric asymmetrical CPCs. This panel is capable of generating $1340 \mathrm{kWh} / \mathrm{m}^{2} /$ year if it is 
installed in Madrid, Spain. Li et al. [64] used the optical-thermal-electric model to predict the output of their CPV design. They showed that if their design were installed in Glasgow, it could generate up to $74.48 \mathrm{kWh} / \mathrm{m}^{2} /$ year.

\section{Key Parameters to Calculate the Annual Electrical Output of an RADTIRC-PV Module}

Specifically for building integration, the concentrator design can be integrated into a building, either be applied in curtain walls, on roofs, in windows or in skylights. As the RADTIRC is static and has a limited acceptance angle for the variation of the position of the sun during the year, the RADTIRC module needs to be installed at the optimum angle of the equinox which is in March or September to capture the sunlight throughout the year. This can be achieved by either: (i) mounting the panels at the optimum tilt angle for March or September; or (ii) mounting the panels at a tilt angle available and then tilting the concentrators inside the panel to the optimum angle.

For applications such double glazed windows, the tilting of concentrators inside the window frame results in an increase in height of the concentrators and therefore larger frame depths are necessary. The concentrator was designed to have a height of $3 \mathrm{~cm}$ so that it could be easily integrated in a standard double-glazed window frame. However, as building integrated PV (BIPV) are subjected to building regulations regarding stability and safety [34], a frame designed specifically for the building integrated CPV (BICPV) application could be considered.

In this work, skylights with PV modules such as the ones illustrated in Figure 5 are taken as an example to show where RADTIRC concentrators could be applied. In this paper, an annual prediction for such an application is carried out for Berlin/Brandenburg, Germany. The comparison between the $\mathrm{CPV}$ and PV modules in this analysis is based on the same area of PV material being used. The standard dimensions of a solar panel are $540 \mathrm{~mm} \times 1200 \mathrm{~mm}$. By subtracting the frame of the module, the approximate active area of the PV module is $0.58 \mathrm{~m}^{2}$. Referring to the manufactured CPV window sample (as illustrated in Figure 3), which has 7.1 times the area of the PV material used, it leads to a CPV module size of $4.1 \mathrm{~m}^{2}$. However, a skylight PV module is generally larger than a conventional PV module due to the gaps left between the cells for room illumination. The PV cell efficiency was determined experimentally and the measured value under standard test conditions was $14.9 \%$ [33]. For the annual prediction, standard test conditions have been assumed.

In order to do the prediction, several key parameters need to be determined, and these will be discussed in the following subsections.

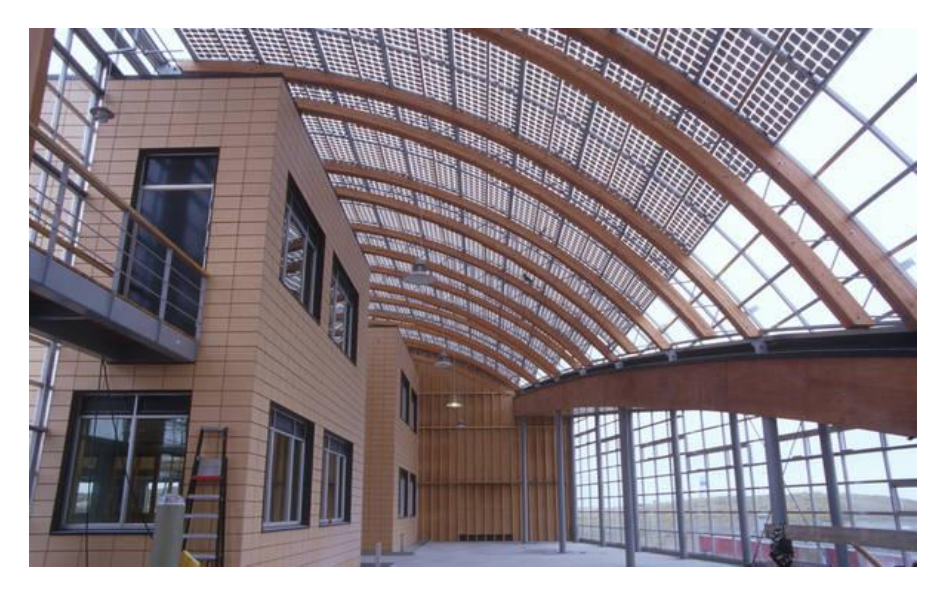

Figure 5. Skylight with monocrystalline PV modules [65].

\subsection{Tilt Angle of the Modules}

The optimum tilt angle for PV modules in Berlin during March/September is $53^{\circ}$ from horizontal facing south according to the online tool provided on [66]. It is important to install the system for 
the spring and autumn equinoxes, so that the angle of incidence on the system does not exceed $23^{\circ}$ throughout the year as shown in Table 3. The angles of incidence for each month were calculated using Equation (1) [67]:

$$
\Theta_{\text {tilt }}=\arccos \left[\left(-\cos \left(\alpha_{s}\right) \times \sin \left(\gamma_{t}\right) \times \cos \left(\alpha_{s}-\alpha_{t}\right)+\sin \left(\gamma_{s}\right) \times \cos \left(\gamma_{t}\right)\right]\right.
$$

where $\gamma_{t}$ is the tilt angle of the plane, $\gamma_{s}$ is the sun altitude angle, $\alpha_{s}$ is the azimuth angle of the sun and $\alpha_{t}$ is the azimuth angle of the tilted surface [67]. The latter is defined as a derivation from the south, which is $180^{\circ}$. The results are presented in Table 3 and correspond to the maximum change of the solar altitude angle during the year, which is $\pm 23^{\circ}$.

Table 3. Optimum tilt angles and angles of incidence at a tilted plane in Berlin.

\begin{tabular}{ccc}
\hline Month & $\begin{array}{c}\text { Maximum Solar } \\
\text { Altitude Angle, } \gamma_{s}\left({ }^{\circ}\right)\end{array}$ & $\begin{array}{c}\text { Maximum Angle of Incidence at } \\
\text { a 53 }\end{array}$ \\
\hline June & 60 & 23 \\
Tilted Plane $\left(^{\circ}\right)$
\end{tabular}

In case a non-tracking PV system is designed for the own-consumption of the building, the tilt angle needs to be adjusted to the month of the year with the lowest irradiance to meet the electricity demand during this month. In Berlin that is the case in December and according to the Photovoltaic Geographical Information System (PVGIS) [68] the optimum tilt angle of the module $\left(\gamma_{t}\right)$ for December is $68^{\circ}$ facing south. As in this prediction, the tilt angle of the module is chosen to be $53^{\circ}$, the system is not optimized for own-consumption purposes.

\subsection{Optical Concentration Gain of the RADTIRC on Tilted Surface}

The analyses were carried out for incidence angles of $8^{\circ}, 16^{\circ}$, and $23^{\circ}$ along the $z$-axis of the concentrator. This represents the change in the solar altitude angle during the year, while the light source is tilted from $-90^{\circ}$ to $+90^{\circ}$ along the $x$-axis representing the path of the sun during the day. The optical concentration gain was calculated, and the results are presented in Figure 6. This represents the effect of direct irradiance on the electrical output of the RADTIRC. The detailed explanation on how to carry out the simulation to obtain the optical concentration gain has been discussed in the authors previously in [33].

When both the angle of incidence along the $z$-axis and along the $x$-axis are increased, it can be seen that the optical concentration gain reduces greatly. Especially at angles of incidence of $\pm 23^{\circ}$ along the $x$-axis, the optical concentration gain experiences a sharp drop after $\pm 20^{\circ}$, with the optical concentration gain being greater than 1 when the angle of incidence is between $\pm 32^{\circ}$. This means that during the months of June and December the acceptance angle during the day is reduced and captures less direct light. The angles of incidence with regards to the solar altitude angle given in Table 3 are based on the maximum angle of the sun's motion during the day. However, since the solar altitude angle varies during the day the angle of incidence on the tilted axis varies. The sun position diagram for Berlin with the designed acceptance angle of $\pm 40^{\circ}$ is shown in Figure 7.

The sun position diagram (Figure 7) shows that during some hours of the day for the months April to August the solar altitude angle is smaller than given in Table 2. Thus, concentration gain during these hours is higher than simulated. On the other hand, the solar altitude angle during some hours of the day for the months September to March is larger than given in Table 3, thus concentration gain is lower than simulated. This needs to be considered during the evaluation of the monthly energy yield. 
As for the optical concentration gain for diffuse irradiance, this has also been investigated previously and the value is $C_{\text {opt }}=1.94$ [60].

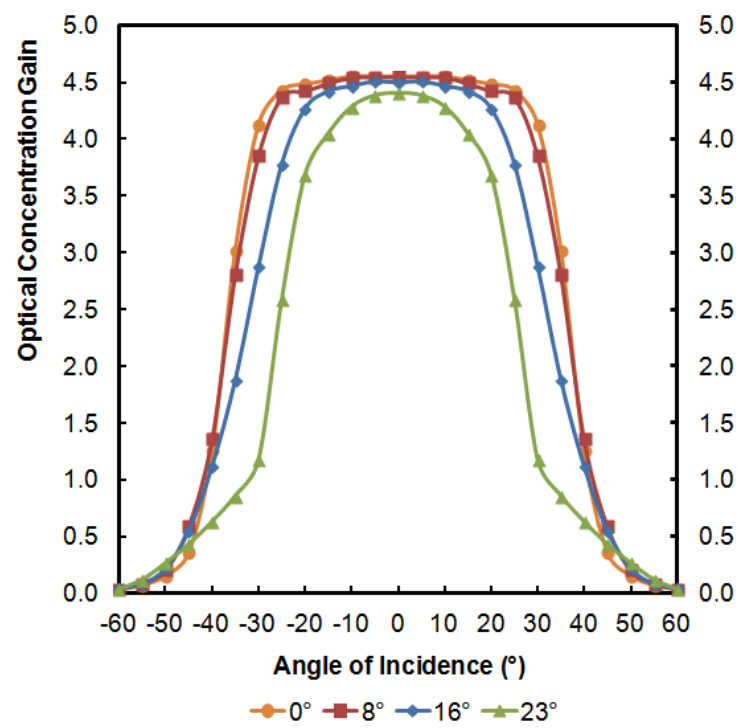

Figure 6. Optical concentration gain for simultaneously varied solar altitude and solar azimuth angles.

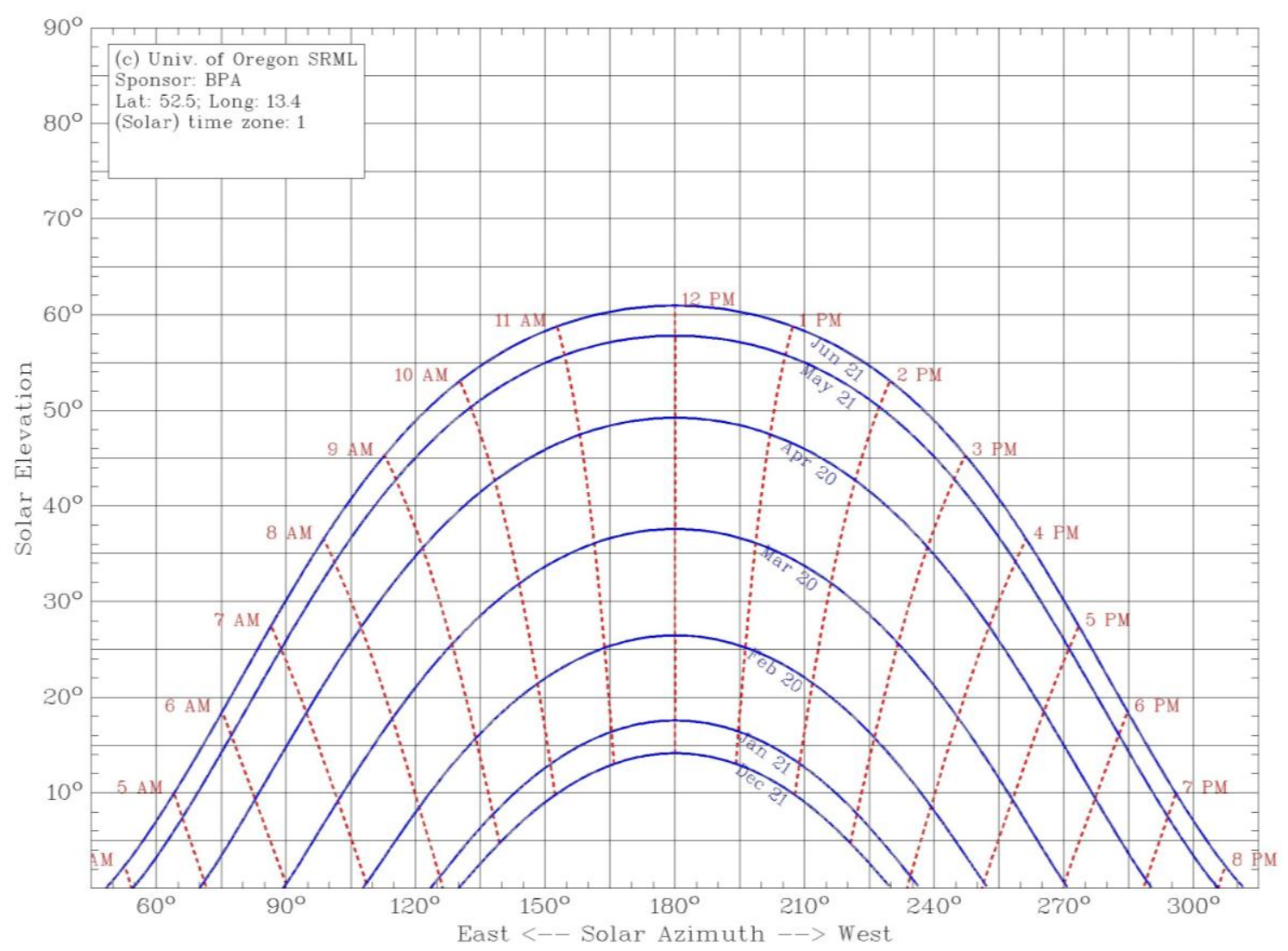

Figure 7. Solar position Diagram for Berlin, Germany $\left(52.5^{\circ} \mathrm{N} 13.4^{\circ} \mathrm{E}\right)[69]$.

\subsection{Irradiation Data}

To predict the annual output, the annual irradiance data for the chosen location, Berlin/ Brandenburg, Germany is needed. The data was provided by the German Meteorological Service 
(DWD) and was recorded in the meteorological observatory in Lindenberg, Brandenburg $\left(52.6^{\circ} \mathrm{N}\right.$, $13.5^{\circ} \mathrm{S}$ ). The global irradiance was measured with a Kipp \& Zonen CM 22 pyranometer and the diffuse irradiance was measured with the same type of pyranometer combined with a tracker shading ball. Global and diffuse irradiance were measured every second and was averaged over the course of a minute. The data at hand is for the year 2004 with global irradiation of $1073 \mathrm{kWh} / \mathrm{m}^{2}$ and diffuse irradiation of $579 \mathrm{kWh} / \mathrm{m}^{2}$ [70].

Since the optical concentration gain is influenced by the solar azimuth angle, the apex of the sun's motion needs to be considered when carrying out the calculation for the energy yield of the RADTIRC-PV system. Therefore, the prediction is carried out by calculating the electrical output for an average day over each month and based on this value the energy yield for a whole month is predicted. The average days were determined numerically and analytically. To validate the acceptance of this model, the real irradiation of each month and the estimated irradiation used in this work was calculated and compared. It was found that the estimation of global irradiation corresponds to the real data. However, the overall estimated diffuse irradiation makes up $58.7 \%$ whereas the irradiance data for the year 2004 gives a diffuse irradiation of $54 \%$ of the global irradiation. Moreover the percentage of diffuse light between 2002 and 2006 averages 51\% [70]. As the concentration gain for direct light is higher than for diffuse, the annual prediction based on this module is more pessimistic than the real case.

Since the RADTIRC-PV module is installed at a tilt angle, diffuse, direct and reflected irradiances on a tilted surface need to be calculated using the provided irradiance data for a horizontal surface. The global irradiance on a tilted surface is the sum of direct irradiance on a tilted surface $E_{d i r, t i l}$, diffuse irradiance on a tilted surface $E_{\text {diff, tilt }}$ and reflected irradiance on a tilted surface $E_{\text {ref,tilt }}$.

Having determined the sun altitude angle $\gamma_{s}$ and having calculated the angle of incidence on a tilted plane $\Theta_{\text {tilt }}$ (see Table 3) using Equation (1), the direct irradiance at a tilted surface is calculated using Equation (2), where $E_{\text {dir, hor }}$ is the direct irradiance on a horizontal plane.

$$
E_{\text {dir,tilt }}=E_{\text {dir, hor }} \times\left[\cos \left(\Theta_{\text {tilt }}\right) / \sin \left(\gamma_{s}\right)\right]
$$

Diffuse irradiance on a tilted surface is calculated using the Klucher model [71], which is an anisotropic approach. It implies the circumsolar brightness around the sun and near the horizon and is more precise than the isotropic approach [67]. The diffuse radiation at a plane with a tilt angle $\gamma_{t}$ is calculated using Equation (3):

$$
E_{\text {diff,tilt }}=E_{\text {diff, }, \text { hor }} \times 0.5 \times\left(1+\cos \left(\gamma_{t}\right) \times\left(1+F \times \sin ^{3}\left(\gamma_{t} / 2\right)\right) \times\left(1+F \times \cos ^{2}\left(\Theta_{\text {tilt }}\right) \times \cos ^{3}\left(\gamma_{s}\right)\right)\right.
$$

where

$$
F=1-\left(E_{\text {diff, hor }} / E_{G, h o r}\right)^{2}
$$

and $E_{\text {diff,hor }}$ and $E_{G, h o r}$ is the diffuse irradiance and the measured global irradiance respectively measured on the horizontal plane. The reflected irradiance was calculated according to Equation (5) [67] and the coefficient Albedo (A) is set as 0.2 for an unknown surface (i.e., the surrounding environment of the building could be made from concrete, wood, metal etc.) [67].

$$
E_{r e f, t i l t}=E_{G, h o r} \times A \times 0.5 \times\left(1-\cos \left(\gamma_{t}\right)\right)
$$

Since the reflected irradiance on a tilted surface does not depend on the solar altitude angle but only on the tilt angle of the plane and the global irradiance, the reflected irradiance is added onto the diffuse irradiance for further calculations. As the concentration gain is calculated for solar azimuth angles between $\pm 90^{\circ}$ in $5^{\circ}$ steps, this corresponds to a change in the suns position in 20 min intervals. Therefore the irradiance data were averaged over 20 min periods. 


\section{Results and Discussion}

The ideal energy yield of the CPV module, $E_{\text {ideal }}$, was calculated for 20 min intervals throughout the day using Equation (6) [67]:

$$
E_{i d e a l}=A_{p v} \times \eta_{p v} \times H_{\text {solar }} \times C_{o p t}
$$

where $A_{p v}$ is the area of the PV material taken as $0.58 \mathrm{~m}^{2}$ (see Section 3), $\eta_{p v}$ is the solar cell efficiency of $14.9 \%$ (see Section 3$), H_{\text {solar }}$ is the solar irradiation and $C_{o p t}$ is the optical concentration gain. For $H_{\text {solar }}, E_{\text {dir,tilt }}$, and the sum of $E_{\text {diff,tilt }}$ and $E_{\text {ref,tilt }}$ are used to get the energy yield under direct and diffuse/reflected irradiance respectively.

The optical concentration gain for direct irradiance was assigned to the irradiation of that particular day. The yearly energy yield of the non-concentrating PV module was calculated to be $116.39 \mathrm{kWh}$ whereas the RADTIRC-PV module had an increased output by a factor of 2.29 providing $266.26 \mathrm{kWh}$ per year. Since the designed geometrical concentration gain is 4.91 , the factor by which the output is increased is lower than desired. However, this can be justified by looking at the yearly irradiation of Berlin. As indicated earlier in Section 3.3, diffuse irradiation makes up to 58.7\% of the global irradiation when summed over the year. As the determined optical concentration gain for diffuse irradiation is only 1.94, more than half of the yearly irradiance is concentrated with the low concentration factor. Figure 8 shows the monthly energy yield for the RADTIRC-PV and the non-concentrating PV modules.

The largest energy yield is achieved with the RADTIRC-PV module in April and September even though the highest irradiance is during June and July as illustrated in Figure 8. This is due to the fact that in April both the irradiance and the optical concentration are high. In September, when the angle of incidence is $0^{\circ}$, the RADTIRC-PV module achieves the highest energy yield even though the irradiance is lower than in April. This shows the strong influence of the angle of incidence on the electrical output with regards to the solar altitude angle.

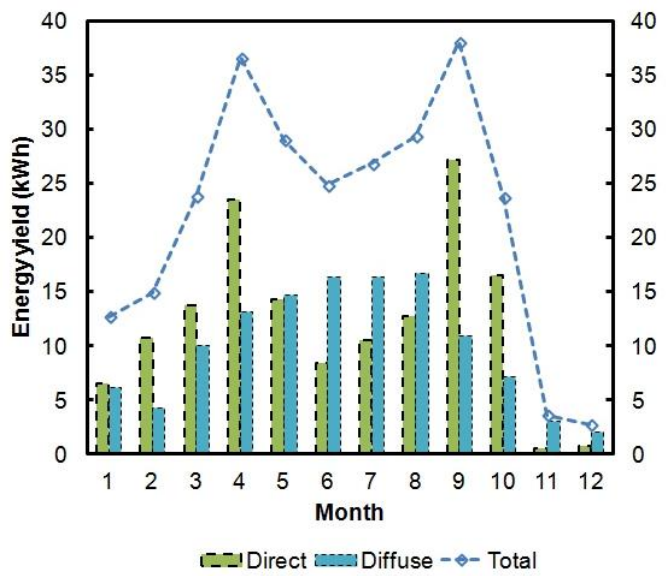

(a) RADTIRC - PV module

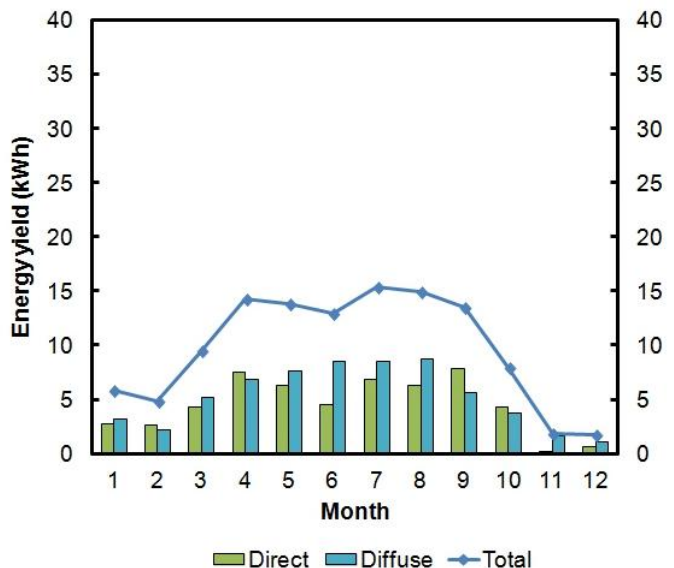

(b) Non-concentrating PV module

Figure 8. Comparison of the monthly energy yield between: (a) an RADTIRC-PV module; and (b) a non-concentrating PV module in Berlin.

The performance of the concentrator during the year under direct and diffuse irradiance is shown in Figure 8 as well. The calculated energy yield output of the RADTIRC-PV module subject to direct irradiance emphasizes that being installed at a $53^{\circ}$ tilt angle, the concentrator does not make the maximum use of the high irradiance during May to July. This is because the angle of incidence on the tilted module during these months is large. However, as discussed in Section 3.2, the concentration gain for the period April until August was taken to be lower than the actual value under real conditions. 
Looking at the performance of the concentrator under diffuse irradiance, the energy yield of the RADTIRC-PV module was nearly doubled throughout the year. In total, the energy yield from diffuse irradiation is $146 \mathrm{kWh}$ and from direct irradiation it is $120 \mathrm{kWh}$ per year. Again, it has to be considered that the estimated diffuse irradiation for Berlin is higher in percentage than the average value shown over the years from 2002 to 2004 .

To illustrate the acceptance of light by the RADTIRC module under direct and diffuse light (labeled as (i) and (ii) respectively), single days in three different months of the year are considered in Figure 9. The three cases show the following: (a) a day in March with high concentration gain and medium irradiation; (b) a day in June with low concentration gain and high irradiation; and (c) a day in December with low concentration gain and low irradiation. The irradiance and the concentration gain are shown as a function of the time during the day.
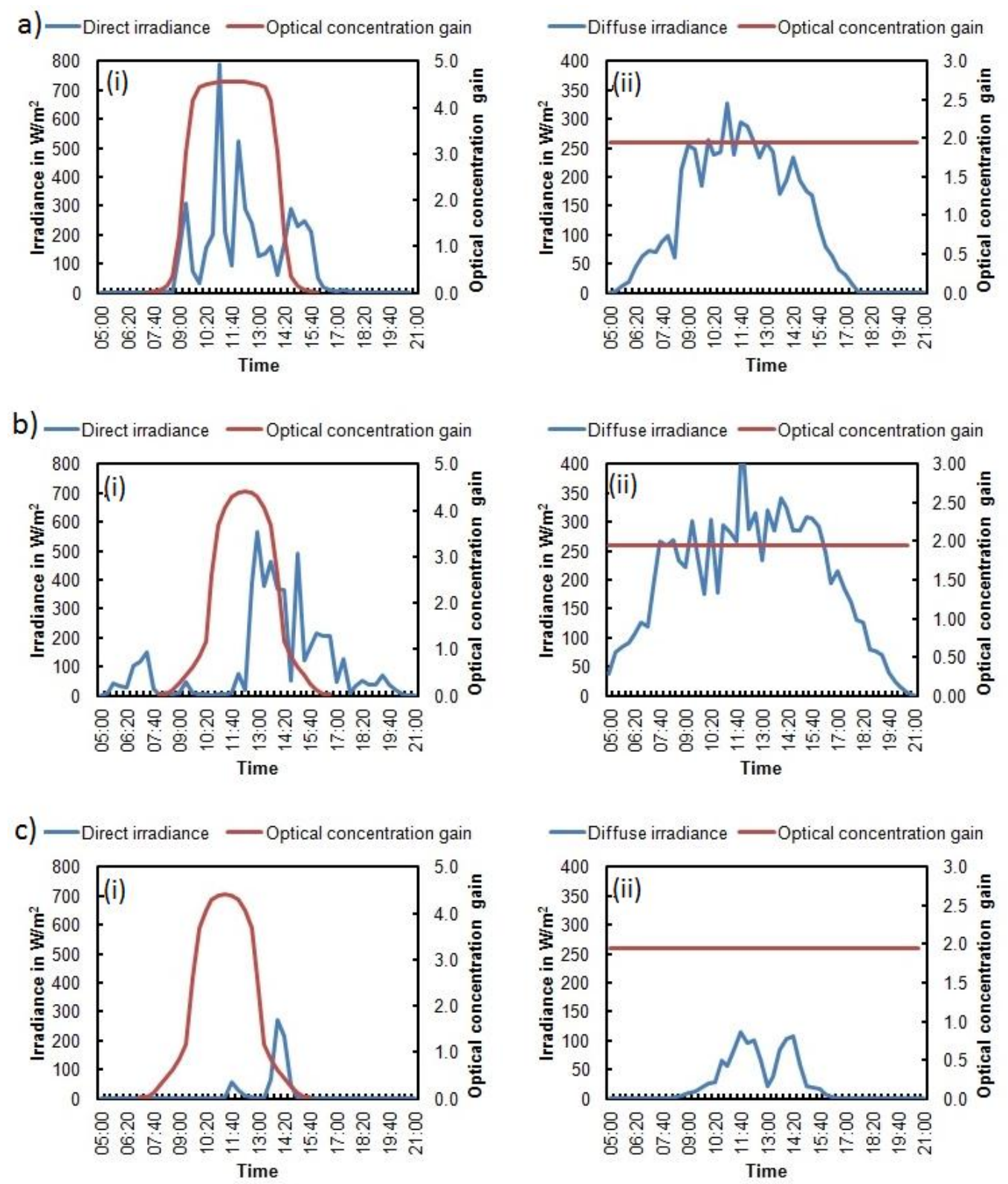

Figure 9. Predicted performance of the RADTIRC-PV module in: (a) March; (b) June; and (c) December in Berlin/Brandenburg. 
It can be seen that in March nearly all direct irradiation throughout the day is within the acceptance angle and is concentrated onto the solar cells. During this month the PV module faces the sun at the optimum angle and the direct irradiance was therefore concentrated by the maximum factor.

In June, the angle of incidence on the tilted plane is $23^{\circ}$ and the acceptance angle is therefore limited. It is therefore likely that the direct irradiation during the day can be entirely accepted by the concentrator. In the given example the main part of the direct irradiation is beyond the acceptance angle and is not concentrated. This shows that for locations like Berlin where direct irradiation makes up only half of the yearly irradiation, a larger acceptance angle is necessary to capture more direct light. A larger acceptance angle will also result in capturing of more diffuse light. However, when the height of the concentrator is kept the same, a larger acceptance angle results in a lower optical concentration gain. Consequently, trade-offs need to be made and the concentrator shape adjusted to the location. The displayed graph for a day in December underlines that a larger acceptance angle is necessary to capture the little amount of direct light. This would also have a favorable impact on the energy yield for the months: November, January and February as diffuse irradiation is the main irradiation during these months. However, it has to be proven that a higher overall energy yield would result from more captured light given a lower $C_{o p t}$ for direct irradiance and a higher $C_{o p t}$ for diffuse.

It has been shown that the annual energy yield of the RADTIRC-PV module for the location of Berlin/Brandenburg is more than doubled when compared to a conventional non-concentrating PV module. The best performance of the concentrators is during the months when the angles of incidence are $\leq 8^{\circ}$ along the $x$-axis. The irradiation during the summer months is concentrated with a reduced optical concentration gain and cannot be entirely captured due to the reduced acceptance angle. During the winter months, the diffuse irradiance makes up a high percentage of the global irradiation and is concentrated with the lower concentration factor that was determined for diffuse irradiance. The overall result shows that for a location like Berlin/Brandenburg, the performance of the concentrator needs to be improved.

One possibility for performance improvement is to change the parameters of the concentrator as already discussed in the previous paragraph. An increased acceptance angle along the $\mathrm{z}$ - and the $x$-axes would result in the capturing of more direct and diffuse light. Thus, the parameters of the concentrator need to be adjusted to each location individually.

Another possibility is to change the arrangement of the concentrators inside the frame. By placing the concentrators on curves as shown in Figure 10, the acceptance angle for direct light during seasonal changes can be increased.

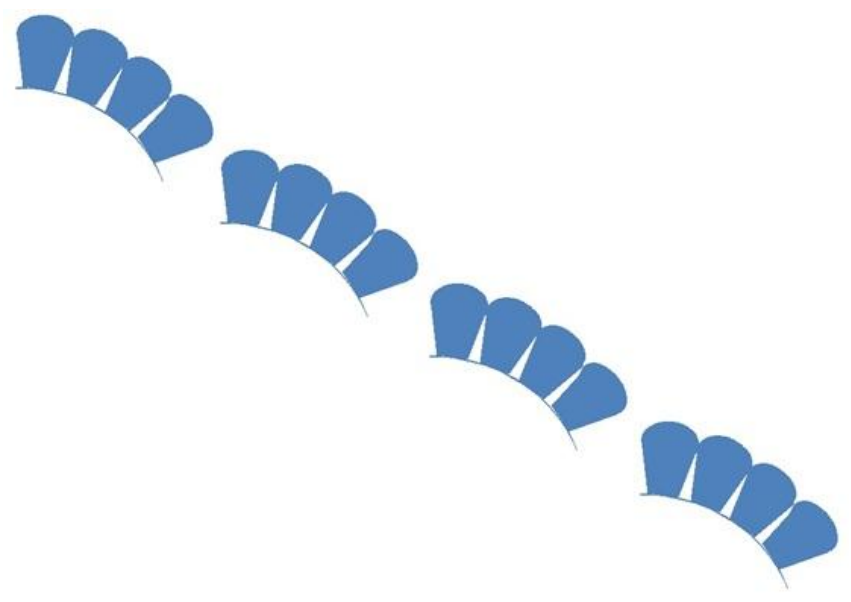

Figure 10. Concentrator arrangements for a larger acceptance angle of the RADTIRC-PV module.

If the shape of a skylight is curved as presented in Figure 10, this technique can be applied to a modular arrangement of the RADTIRC systems. However, the fabrication and assembly of such 
modules is more complicated. Furthermore, each row of concentrators along the horizontal axis is exposed to a different level of irradiance which leads to a variation of the solar cell temperature of each row. Since the CPV module would benefit from a cooling system to maintain the solar cell efficiency, such arrangement of concentrators would require a more complex cooling system, as it might have to be adjusted for each row specifically.

Depending on the political framework, if a feed-in tariff is granted and if the building is grid-connected, the electricity generated from the system could be sold and therefore a maximized yearly energy output is desirable. In this case, considering that diffuse irradiation is low during the months between November and February, the tilt angle of the module can be set at the recommended tilt angle, which is $37^{\circ}$ for the location Berlin/Brandenburg according to PVGIS [68]. This will lead to a smaller angle of incidence during the summer months and improve the capture efficiency of direct irradiation during these months. Additionally, the diffuse irradiation that is dominant during the winter months is higher at smaller tilt angles and would lead to a higher energy yield for diffuse irradiation. Nevertheless, this leads to a high electrical output during the summer and a low electrical output during the winter. In this case, LCPV systems which are designed to supply the building constantly throughout the year would require a larger backup system.

\section{Conclusions}

The annual prediction of utilizing an RADTIRC-PV module as a skylight installed theoretically in Berlin/Brandenburg, Germany was calculated and compared with a non-concentrating PV module. Based on the simulation results, it was found that the yearly energy yield was increased by a factor of 2.29 when the RADTIRC-PV system was compared with the non-concentrating version. It has been shown that a tilt angle optimized for the month of the equinox reduces the performance of the concentrator during the summer months. To improve the performance of the concentrator, an increased half-acceptance angle of the concentrator or a different tilt angle of the system was suggested. The concentrator parameters also need to be adjusted to each location specifically depending on the irradiation and the longitude of the location. However, for a more exact prediction, the change of the sun altitude angle during the day needs to be considered yielding an improved concentration gain for each hour of the day. Also, losses must be taken into consideration because they reduce the performance of the RADTIRC. This includes losses due to manufacturing errors, misalignment during assembly process, dust and soil accumulation, shadowing, overheating etc. [61,72,73].

As a conclusion, it has been demonstrated that the RADTIRC has the capability to improve the electrical output when compared with a non-concentrating system containing the same amount of PV material. Taking into account the savings in PV material, increased natural illumination and potential heat generation, the attractiveness of implementing BIPV systems is increased. As a result, the BICPV technology can help achieve the EU target of having more zero carbon buildings, an improved technology efficiency, and a higher share of energy generated from renewable sources.

Further research could be done to investigate cooling possibilities of the system to reduce the temperature of the PV cell. An air or water-based cooling system carries waste heat that can be used for space heating, generating hot water or even cooling. Owing to the fact that the RADTIRC is made from transparent material, another analysis that could be carried out is the illumination properties of the designs. Any rays outside the acceptance angle of the concentrator and in-between the entrance apertures of the concentrators will pass through their side profile into a building, providing natural illumination in the building interior. This analysis will enable the quantification of the reduction of the electricity requirements for lighting purposes in a building and an optimization of the design for optimum illumination.

Acknowledgments: The author would like to thank Glasgow Caledonian University, Ministry of Higher Education (MOHE) Malaysia, Universiti Teknologi Malaysia (UTM) (Research cost center no. R.K130000.7740.4J315) and the support of the Chilean Research Council (CONICYT) under the project Fondecyt 11160115 for funding this research project. 
Author Contributions: D.F., S.H.A.-B., F.M.-S. and R.R.-I. conceived and designed the simulations and experiments; A.B.M., S.H.M.Y. and M.E.K. wrote the non-technical "Introduction" and investigated the renewable energy policy; D.F., S.H.A.-B., F.M.-S. and R.R.-I. wrote the paper; N.A.B., A.A.M. and J.A.A.-R. extensively reviewed the paper, provided areas of improvement and added substantive information.

Conflicts of Interest: The authors declare no conflict of interest.

\section{References}

1. United Nations. Goal 7: Ensure Access to Affordable, Reliable, Sustainable and Modern Energy for All. Available online: http:/ / www.un.org/sustainabledevelopment/energy / (accessed on 7 December 2016).

2. United Nations. Sustainable Development Knowledge Platform. Available online: https:// sustainabledevelopment.un.org/sdg7 (accessed on 7 December 2016).

3. IRENA. Sustainable Energy for All and SDG 7 in Focus. Available online: https: / /irenanewsroom.org/2015/ 09/30/sustainable-energy-for-all-and-sdg-7-in-focus/ (accessed on 7 December 2016).

4. IPCC. Climate Change 2014: Mitigation of Climate Change. Contribution of Working Group III to the Fifth Assessment Report of the Intergovernmental Panel on Climate Change; Cambridge University Press: Cambridge, UK; New York, NY, USA, 2014.

5. Chen, C.J. Physics of Solar Energy; John Wiley \& Sons: New Jersey, NJ, USA, 2011; ISBN 9781118044599.

6. Lewis, N.S.; Nocera, D.G. Powering the planet: chemical challenges in solar energy utilization. Proc. Natl. Acad. Sci. USA 2006, 103, 15729-15735. [CrossRef] [PubMed]

7. International Energy Agency (IEA). Energy Technology Perspectives 2014: Executive Summary; IEA: Paris, France, 2014.

8. Luque, A.; Hegedus, S. Handbook of Photovoltaic Science and Engineering, 2nd ed.; John Wiley and Sons, Ltd.: New Jersey, NJ, USA, 2010.

9. Renewable Energy Policy Network for the 21st Century (REN 21). Renewables 2017: Global Status Report; REN 21: Paris, France, 2017.

10. International Energy Agency-Photovoltaic Power System Programme (IEA-PVPS). Trends 2016 in Photovoltaic Applications; IEA-PVPS: St. Ursen, Switzerland, 2016.

11. International Renewable Energy Agency (IRENA). Renewable Energy Technologies: Cost Analysis Series-Solar Photovoltaics; IRENA: Abu Dhabi, UAE, 2012.

12. Lo, C.-C.; Wang, C.-H.; Huang, C.-C. The national innovation system in the Taiwanese photovoltaic industry: A multiple stakeholder perspective. Technol. Forecast. Soc. Chang. 2013, 80, 893-906. [CrossRef]

13. Goodrich, A.; Hacke, P.; Wang, Q.; Sopori, B.; Margolis, R.; James, T.L.; Woodhouse, M. A wafer-based monocrystalline silicon photovoltaics road map: Utilizing known technology improvement opportunities for further reductions in manufacturing costs. Sol. Energy Mater. Sol. Cells 2013, 114, 110-135. [CrossRef]

14. Munir, A.B.; Muhammad-Sukki, F.; Bani, N.A. Renewables: Solar energy needs focus. Nature 2016, $529,466$. [CrossRef] [PubMed]

15. Swanson, R.M. Photovoltaic Concentrators. In Handbook of Photovoltaic Science and Engineering; John Wiley \& Sons, Ltd.: New Jersey, NJ, USA, 2003; pp. 449-503. ISBN 9780470014004.

16. Muhammad-Sukki, F.; Ramirez-Iniguez, R.; Mcmeekin, S.G.; Stewart, B.G.; Clive, B. Solar concentrators. Int. J. Appl. Sci. 2010, 1, 1-15.

17. Sarmah, N. Design and Performance Evaluation of a Low Concentrating Line-Axis Dielectric Photovoltaic System. Ph.D. Thesis, Heriot-Watt University, Edinburgh, UK, 2012.

18. Welford, W.T.; Winston, R. High Collection Nonimaging Optics; Academic Press: Cambridge, MA, USA, 1989; ISBN 9780127428857.

19. Chaves, J. Introduction to Nonimaging Optics; CRC Press: Boca Raton, FL, USA, 2008; ISBN 978-1420054293.

20. Winston, R.; Miñano, J.C.; Benítez, P.; Shatz, N.; Bortz, J.C. Nonimaging Optics; Academic Press: Cambridge, MA, USA, 2005; ISBN 9780127597515.

21. Ramirez-Iniguez, R.; Idrus, S.M.; Sun, Z. Optical Wireless Communications: IR for Wireless Connectivity; AUERBACH Publication: Boca Raton, FL, USA, 2008; ISBN 978-0849372094.

22. Rabl, A. Comparison of solar concentrators. Sol. Energy 1976, 18, 93-111. [CrossRef]

23. Philipps, S.P.; Bett, A.W.; Horowitz, K.; Kurtz, S. Current Status of Concentrator Photovoltaic (CPV) Technology; National Renewable Energy Laboratory (NREL): Lakewood, CO, USA, 2016. 
24. Baig, H.; Mallick, T.K. Challenges and opportunities in concentrating photovoltaic research. Mod. Energy Rev. 2011, 3, 18-26.

25. Chemisana, D. Building Integrated Concentrating Photovoltaics: A review. Renew. Sustain. Energy Rev. 2011, 15, 603-611. [CrossRef]

26. Norton, B.; Eames, P.C.; Mallick, T.K.; Huang, M.J.; McCormack, S.J.; Mondol, J.D.; Yohanis, Y.G. Enhancing the performance of building integrated photovoltaics. Sol. Energy 2011, 85, 1629-1664. [CrossRef]

27. Chemisana, D.; Zacharopoulos, A. Building-Integration of High-Concentration Photovoltaic Systems. In High Concentrator Photovoltaics; Springer: Cham, Switzerland, 2015; pp. 353-376.

28. Abu-Bakar, S.H.; Muhammad-Sukki, F.; Freier, D.; Ramirez-Iniguez, R.; Mallick, T.K.; Munir, A.B.; Mohd Yasin, S.H.; Abubakar Mas'ud, A.; Md Yunus, N. Optimisation of the performance of a novel rotationally asymmetrical optical concentrator design for building integrated photovoltaic system. Energy 2015, 90, 1033-1045. [CrossRef]

29. Sick, F.; Erge, T. Photovoltaics in Buildings: A Design Handbook for Architects and Engineers, 1st ed.; Routledge: Abingdon, UK, 1996.

30. Lowder, T. The Challenges of Building-Integrated Photovoltaics. Available online: Www. renewableenergyworld.com/articles/2012/05/the-challenges-building-integrated-photovoltaics.html (accessed on 16 April 2016).

31. James, T.; Goodrich, A.; Woodhouse, M.; Margolis, R.; Ong, S. Building-Integrated Photovoltaics (BIPV) in the Residential Sector: An Analysis of Installed Rooftop System Prices; National Renewable Energy Laboratory (NREL): Lakewood, CO, USA, 2011.

32. GTM Research. Building-Integrated Photovoltaics: An Emerging Market; GTM Research: Boston, MA, USA, 2010.

33. Freier, D.; Muhammad-Sukki, F.; Abu-Bakar, S.H.; Ramirez-Iniguez, R.; Abubakar Mas'ud, A.; Albarracín, R.; Ardila-Rey, J.A.; Munir, A.B.; Mohd Yasin, S.H.; Bani, N.A. Software simulation and experimental characterisation of a rotationally asymmetrical concentrator under direct and diffuse solar radiation. Energy Convers. Manag. 2016, 122, 223-238. [CrossRef]

34. Sellami, N. Design and Characterisation of a Novel Translucent Solar Concentrator. Ph.D. Thesis, Heriot-Watt University, Edinburgh, UK, 2013.

35. Polysolar. Guide to BIPV; Polysolar Limited: Cambridge, UK, 2015.

36. Muhammad-Sukki, F.; Ramirez-Iniguez, R.; McMeekin, S.G.; Stewart, B.G.; Clive, B. Optimisation of concentrator in the Solar Photonic Optoelectronic Transformer: Comparison of geometrical performance and cost of implementation. Renew. Energy Power Qual. J. 2011, 9, 1-6. [CrossRef]

37. ICC Evaluation Service. Acceptance Criteria for Building-Integrated Photovoltaic (BIPV) Roof Covering Systems; ICC Evaluation Service: Brea, CA, USA, 2011.

38. Muhammad-Sukki, F.; Abu-Bakar, S.H.; Ramirez-Iniguez, R.; McMeekin, S.G.; Stewart, B.G.; Sarmah, N.; Mallick, T.K.; Munir, A.B.; Mohd Yasin, S.H.; Abdul Rahim, R. Mirror symmetrical dielectric totally internally reflecting concentrator for building integrated photovoltaic systems. Appl. Energy 2014, 113, 32-40. [CrossRef]

39. Abu-Bakar, S.H.; Muhammad-Sukki, F.; Freier, D.; Ramirez-Iniguez, R.; Mallick, T.K.; Munir, A.B.; Mohd Yasin, S.H.; Abubakar Mas'ud, A.; Md Yunus, N. Performance analysis of a novel rotationally asymmetrical compound parabolic concentrator. Appl. Energy 2015, 154, 221-231. [CrossRef]

40. Abu-Bakar, S.H.; Muhammad-Sukki, F.; Ramirez-Iniguez, R.; Freier, D.; Mallick, T.K.; Munir, A.B.; Mohd Yasin, S.H.; Abubakar Mas'ud, A.; Bani, N.A. Novel optical concentrator technology for building integrated photovoltaic systems. In Proceedings of the 2016 World Conference on Innovation, Engineering, and Technology (IET 2016), Sapporo, Japan, 24-26 June 2016; pp. 355-365.

41. Ramirez-Iniguez, R.; Deciga-Gusi, J.; Freier, D.; Abu-Bakar, S.H.; Muhammad-Sukki, F. Experimental evaluation of a solar window incorporating rotationally asymmetrical compound parabolic concentrators (RACPC). Energy Proced. 2017, 130, 102-107. [CrossRef]

42. Singh, H.; Sabry, M.; Redpath, D.A. Experimental investigations into low concentrating line axis solar concentrators for CPV applications. Sol. Energy 2016, 136, 421-427. [CrossRef]

43. Bojić, M.; Marjanović, N.; Miletić, I.; Bojić, L. Comparison of optical performances of sea-shell trough solar concentrators. Energy Build. 2015, 98, 144-150. [CrossRef]

44. Wu, Y.; Connelly, K.; Liu, Y.; Gu, X.; Gao, Y.; Chen, G.Z. Smart solar concentrators for building integrated photovoltaic façades. Sol. Energy 2016, 133, 111-118. [CrossRef] 
45. Meng, X.; Sellami, N.; Knox, A.R.; Montecucco, A.; Siviter, J.; Mullen, P.; Ashraf, A.; Samarelli, A.; Llin, L.F.; Paul, D.J.; et al. A novel absorptive/reflective solar concentrator for heat and electricity generation: An optical and thermal analysis. Energy Convers. Manag. 2016, 114, 142-153. [CrossRef]

46. Slooff, L.H.; Bende, E.E.; Burgers, A.R.; Budel, T.; Pravettoni, M.; Kenny, R.P.; Dunlop, E.D.; Büchtemann, A. A luminescent solar concentrator with 7.1\% power conversion efficiency. Phys. Status Solidi Rapid Res. Lett. 2008, 2, 257-259. [CrossRef]

47. Lo, C.K.; Lim, Y.S.; Tan, S.G.; Rahman, F.A. A new hybrid algorithm using thermodynamic and backward ray-tracing approaches for modeling luminescent solar concentrators. Energies 2010, 3, 1831-1860. [CrossRef]

48. Pei, G.; Li, G.; Su, Y.; Ji, J.; Riffat, S.; Zheng, H. Preliminary ray tracing and experimental study on the effect of mirror coating on the optical efficiency of a solid dielectric compound parabolic concentrator. Energies 2012, 5, 3627-3639. [CrossRef]

49. Vu, N.; Shin, S. A concentrator photovoltaic system based on a combination of prism-compound parabolic concentrators. Energies 2016, 9, 645. [CrossRef]

50. Tien, N.; Shin, S. A novel concentrator photovoltaic (CPV) system with the improvement of irradiance uniformity and the capturing of diffuse solar radiation. Appl. Sci. 2016, 6, 251. [CrossRef]

51. Liu, X.; Wu, Y.; Hou, X.; Liu, H. Investigation of the optical performance of a novel planar static PV concentrator with Lambertian rear reflectors. Buildings 2017, 7, 88. [CrossRef]

52. Meng, X.-L.; Xia, X.-L.; Dai, G.-L.; Guene Lougou, B.; Wu, S.-L. A vector based freeform approach for reflecting concentrator of solar energy. Sol. Energy 2017, 153, 691-699. [CrossRef]

53. Selvaraj, P.; Baig, H.; Mallick, T.K.; Siviter, J.; Montecucco, A.; Li, W.; Paul, M.; Sweet, T.; Gao, M.; Knox, A.R.; et al. Enhancing the efficiency of transparent dye-sensitized solar cells using concentrated light. Sol. Energy Mater. Sol. Cells 2018, 175, 29-34. [CrossRef]

54. van Dijk, L.; Marcus, E.A.P.; Oostra, A.J.; Schropp, R.E.I.; Di Vece, M. 3D-printed concentrator arrays for external light trapping on thin film solar cells. Sol. Energy Mater. Sol. Cells 2015, 139, 19-26. [CrossRef]

55. Price, J.S.; Sheng, X.; Meulblok, B.M.; Rogers, J.A.; Giebink, N.C. Wide-angle planar microtracking for quasi-static microcell concentrating photovoltaics. Nat. Commun. 2015, 6, 6223. [CrossRef] [PubMed]

56. Abu-Bakar, S.H.; Muhammad-Sukki, F.; Freier, D.; Ramirez-Iniguez, R.; Mallick, T.K.; Munir, A.B.; Mohd Yasin, S.H.; Abubakar Mas'ud, A.; Abu-Bakar, S.S.; Bani, N.A.; et al. Potential of implementing the low concentration photovoltaic systems in the United Kingdom. Int. J. Electr. Comput. Eng. 2017, 7, 1398-1405. [CrossRef]

57. Sarmah, N.; Richards, B.S.; Mallick, T.K. Design, development and indoor performance analysis of a low concentrating dielectric photovoltaic module. Sol. Energy 2014, 103, 390-401. [CrossRef]

58. Ramirez-Iniguez, R.; Muhammad-Sukki, F.; McMeekin, S.G.; Stewart, B.G. Optical element. U.S. Patent 20140345689A1, 27 November 2014.

59. Muhammad-Sukki, F.; Abu-Bakar, S.H.; Ramirez-Iniguez, R.; McMeekin, S.G.; Stewart, B.G.; Munir, A.B.; Mohd Yasin, S.H.; Abdul Rahim, R. Performance analysis of a mirror symmetrical dielectric totally internally reflecting concentrator for building integrated photovoltaic systems. Appl. Energy 2013, 111, 288-299. [CrossRef]

60. Freier, D.; Muhammad-Sukki, F.; Abu-bakar, S.H.; Ramirez-Iniguez, R.; Munir, A.B.; Mohd Yasin, S.H.; Abubakar Mas'ud, A.; Bani, N.A. Effect of Diffuse Radiation on the Performance of a Rotationally Asymmetrical Optical Concentrator. In Proceedings of the 2016 IEEE 6th International Conference on Photonics (ICP2016), Kuching, Sarawak,Malaysia, 14-17 March 2016; IEEE: New Jersey, NJ, USA, 2016; pp. 71-73.

61. Abu-Bakar, S.H.; Muhammad-Sukki, F.; Freier, D.; Ramirez-Iniguez, R.; Mallick, T.K.; Munir, A.B.; Mohd Yasin, S.H.; Abubakar Mas'ud, A.; Bani, N.A. Performance analysis of a solar window incorporating a novel rotationally asymmetrical concentrator. Energy 2016, 99, 181-192. [CrossRef]

62. Lamnatou, C.; Baig, H.; Chemisana, D.; Mallick, T.K. Dielectric-based 3D building-integrated concentrating photovoltaic modules: An environmental life-cycle assessment. Energy Build. 2017, 138, 514-525. [CrossRef]

63. Baig, H.; Fernández, E.F.; Mallick, T.K. Influence of spectrum and latitude on the annual optical performance of a dielectric based BICPV system. Sol. Energy 2016, 124, 268-277. [CrossRef]

64. Li, W.; Paul, M.C.; Rolley, M.; Sweet, T.; Gao, M.; Baig, H.; Fernandez, E.F.; Mallick, T.K.; Montecucco, A.; Siviter, J.; et al. A coupled optical-thermal-electrical model to predict the performance of hybrid PV/T-CCPC roof-top systems. Renew. Energy 2017, 112, 166-186. [CrossRef] 
65. ECN. Architects Just Want to Develop Attractive Buildings. Available online: https://www.ecn.nl/nl/ nieuws/newsletter-en/2009/june-2009/solar-energy-architecture/ (accessed on 10 November 2017).

66. Boxwell, M. Solar Electricity Handbook; Green Stream Publishing: London, UK, 2015; ISBN 190767053X.

67. Quaschning, V. Understanding Renewable Energy Systems, 1st ed.; Earthscan: Bath, UK, 2005; ISBN 1-84407-128-6.

68. Joint Research Centre and Institue for Energy and Transport. Photovoltaic Geographical Information System (PVGIS). Available online: http:/ / re.jrc.ec.europa.eu/pvgis / (accessed on 28 October 2015).

69. University of Oregon. Sun Path Chart Program. Available online: http://solardat.uoregon.edu/ SunChartProgram.html (accessed on 16 November 2017).

70. Weniger, J. Dimensionierung und Netzintegration von PV-Speichersystemen. Master's Thesis, University of Applied Sciences, Berlin, Germany, 2013.

71. Klucher, T.M. Evaluation of models to predict insolation on tilted surfaces. Sol. Energy 1979, 23, 111-114. [CrossRef]

72. Baig, H.; Heasman, K.C.; Mallick, T.K. Non-uniform illumination in concentrating solar cells. Renew. Sustain. Energy Rev. 2012, 16, 5890-5909. [CrossRef]

73. Bowden, S.; Wenham, S.R.; Coffey, P.; Dickinson, M.; Green, M.A. High efficiency photovoltaic roof tile with static concentrator. Proceedings of the Conference Record of the Twenty Third IEEE Photovoltaic Specialists Conference-1993, (Cat. No.93CH3283-9), Louisville, KY, USA, 10-14 May 1993; IEEE: New Jersey, NJ, USA, 1993; pp. 1068-1072.

(C) 2018 by the authors. Licensee MDPI, Basel, Switzerland. This article is an open access article distributed under the terms and conditions of the Creative Commons Attribution (CC BY) license (http://creativecommons.org/licenses/by/4.0/). 